\title{
RESENHA
}

\section{Métodos em pesquisa comportamental}

\author{
Paula Inez Cunha Gomide \\ Universidade Federal do Paraná \\ Emma Otta \\ Universidade de São Paulo
}

Livro: Cozby, Paul C. (2001). Métodos em Pesquisa Comportamental. California: Mayfield Publishing Co.

O livro "Methods in Behavioral Research", de Paul Cozby, está na $7^{\mathrm{a}}$ edição (2001) e foi publicado pela Mayfield Publishing Company. Foi traduzido por Emma Otta (Psicologia Experimental - USP) e Paula Inez Cunha Gomide (Psicologia da Infância e da Adolescência - UFPR) e será publicado, pela Atlas, brevemente.

Através de uma linguagem simples e didática, o autor aborda conceitos de metodologia científica, trazendo pesquisas recentes e representativas da área da psicologia, que são utilizadas para exemplificar os princípios metodológicos referenciados. Raramente se encontra um livro de metodologia científica voltado especificamente para alunos de psicologia como este. Cada capítulo tem, ao final, um conjunto de perguntas de revisão e questões de discussão que facilitam o entendimento da abordagem metodológica proposta e permitem que os alunos exercitem os conceitos aprendidos, tanto de forma individual como coletivamente.

O livro começa com um capítulo que demonstra ao estudante como descobrir ou procurar seu problema de estudo, discutindo as fontes naturais de pesquisa; em seguida, didaticamente, o autor ensina como fazer uma adequada revisão da literatura utilizando o
PsycInfo e listando as principais revistas internacionais nomeadas pela APA. O terceiro capítulo trata da Ética na Pesquisa e utiliza, para ilustrar os pressupostos éticos, uma série de pesquisas que foram alvo de críticas éticas ao longo dos últimos anos, comentado-as e ressaltando as consequiências das escolhas feitas pelos pesquisadores.

A partir do quarto até o décimo quarto capítulo o autor apresenta os procedimentos metodológicos para coleta e análise de dados e acrescenta as análises estatísticas comumente usadas em pesquisas psicológicas, acompanhadas de anexos, que auxiliam o estudante na execução dos exercícios.

Muito interessante é o Apêndice A, onde Cozby detalha todos os passos para a elaboração de um artigo de pesquisa, de acordo com as normas da APA (American Psychological Association), incluindo, inclusive, um artigo modelo (muito interessante, por sinal).

Impossível permanecer ingênuo em pesquisa após ter percorrido com cuidado os capítulos do livro de Paul Cozby. Este livro tem sido usado pelas tradutoras em seus cursos de metodologia científica tanto da graduação como da pós-graduação, com bastante êxito.

Sobre as autoras da resenha

Paula Inez Cunha Gomide: Professora e Pesquisadora do Programa de Pós-Graduação em Psicologia da Infância e da Adolescência da Universidade Federal do Paraná. Doutora em Psicologia Experimental pela Universidade de São Paulo.

Emma Otta: Professora e Pesquisadora do Programa de Pós-Graduação em Psicologia Experimental da Universidade de São Paulo. Doutora em Psicologia Experimental pela Universidade de São Paulo. 
